University of Nebraska - Lincoln

DigitalCommons@University of Nebraska - Lincoln

Agronomy \& Horticulture -- Faculty Publications

Agronomy and Horticulture Department

$9-1-2000$

\title{
Crop Rotation and Nitrogen Effects on Normalized Grain Yields in a Long-Term Study
}

Gary E. Varvel

University of Nebraska-Lincoln, gevarvel@windstream.net

Follow this and additional works at: https://digitalcommons.unl.edu/agronomyfacpub

Part of the Plant Sciences Commons

Varvel, Gary E., "Crop Rotation and Nitrogen Effects on Normalized Grain Yields in a Long-Term Study" (2000). Agronomy \& Horticulture -- Faculty Publications. 11.

https://digitalcommons.unl.edu/agronomyfacpub/11

This Article is brought to you for free and open access by the Agronomy and Horticulture Department at DigitalCommons@University of Nebraska - Lincoln. It has been accepted for inclusion in Agronomy \& Horticulture -Faculty Publications by an authorized administrator of DigitalCommons@University of Nebraska - Lincoln. 


\title{
Crop Rotation and Nitrogen Effects on Normalized Grain Yields in a Long-Term Study
}

\author{
Gary E. Varvel*
}

\begin{abstract}
Effects of year-to-year variability in agricultural production systems have always been a concern, but few studies are conducted for a long enough period of time where management system evaluations and assessments can be made. Given this limitation, questions about whether management systems are effective at reducing temporal variability remain in production agriculture. These questions prompted investigation of a long-term crop rotation study to determine effects of crop rotation and $\mathbf{N}$ fertilization practices in a rainfed environment on normalized grain yields. Sixteen years of grain yield data from an experiment with seven cropping systems (three monoculture, two 2yr rotations, and two 4-yr rotations) and three $\mathbf{N}$ fertilizer rates are included in the study. Grain yields from 1983 through 1998 for each crop and $\mathbf{N}$ fertilizer treatment were normalized and then relative grain yield within a cropping system and $\mathbf{N}$ fertilizer treatment were combined, which resulted in relative yields for each cropping system and $\mathbf{N}$ fertilizer treatment combination in each year. Using the normalized yields, overall analyses of the $16 \mathrm{yr}$ of data were conducted to assess what effects cropping systems and $\mathbf{N}$ fertilizer have on yield variability. These analyses demonstrated that crop rotation systems are more effective at reducing long-term yield variability than monoculture systems, even with $\mathbf{N}$ fertilizer. As expected, $\mathbf{N}$ fertility, obtained from either fertilizer or legumes in monoculture or rotation systems, is probably one of the most, if not the most important aspect in reducing yield variability. Analyses of normalized yields also demonstrated that reductions in yield variability could be obtained in many of our cropping systems with proper management.
\end{abstract}

$\mathrm{V}$ ARIABILITY, both spatial and temporal, has long been a concern for workers in agriculture. Historically, when fields were first broken out of native grass or forest areas they were small, and even though they were managed as a single unit the amount of variability they encompassed was relatively small. Development of larger equipment and mechanization has resulted in the tendency to combine many of these smaller fields into one large field, which from the standpoint of physical management made these fields easier to manage and allowed farmers to cover more acreage in a much shorter time period. At the same time, this has resulted in much larger fields being managed as single units, which generally encompass more variability.

Agronomists have long recognized that spatial and temporal variability greatly affects crop production and have tried to some extent to reduce those effects. Hybrid and variety development, fertilizer use, and irrigation where water is available have been used successfully in many areas to reduce or minimize some of the effects of variability. These practices have generally resulted in improved average yields over the long term, but little

G.E. Varvel, USDA-ARS and Dep. of Agronomy, Univ. of Nebraska, Lincoln, NE 68583. Joint contribution of USDA-ARS and the Nebraska Agric. Res. Div., Journal Ser. no. 12880. Received 3 Jan. 2000. *Corresponding author (gvarvel1@unl.edu).

Published in Agron. J. 92:938-941 (2000). information is available on their effect on year-toyear variability.

There have been several attempts to analyze what effect these different aspects of management may have on both spatial and temporal variability of yield. Finlay and Wilkinson (1963), Mead et al. (1986), and Raun et al. (1993) used stability analysis to evaluate fertility treatments or genotypes for stability across time or location. As noted by Eghball and Varvel (1997), stability analysis should not be used for comparisons including dissimilar crops because of the scale dependency of the analysis.

Eghball and Varvel (1997) used fractal analysis to analyze yields from selected treatments in a large longterm study to assess temporal variability. This same procedure was used by Eghball and Power (1995) to characterize temporal variability for average yield of 10 crops in the United States. In both cases, results indicated that crops were significantly different in terms of temporal variability and that management was having little effect on spatial variability because of the dominance of temporal variability. These results seem to indicate that management can do little to overcome temporal variability, unless the environmental factors affecting it can be lessened to some extent, such as using irrigation to alleviate water stress.

Crop and soil management effects observed over time by researchers, consultants, and farmers seem to contradict these conclusions. Based on these observations, our objective was to use results from a long-term crop rotation study designed to determine effects of crop rotation and $\mathrm{N}$ fertilization practices in a rainfed environment on yield variability by using normalized grain yields from those systems.

\section{MATERIALS AND METHODS}

The experiment was located on the Agronomy Farm at the University of Nebraska Agricultural Research and Development Center near Mead, Nebraska on a well-drained Sharpsburg silty clay loam (fine, smectitic, mesic Typic Argiudoll) with an organic matter content of $31 \mathrm{~g} \mathrm{~kg}^{-1}$ in the upper $75 \mathrm{~mm}$. Soil test $\mathrm{P}$ and $\mathrm{K}$ levels in the upper $75 \mathrm{~mm}$ were in the very high categories (according to University of Nebraska Soil Testing Laboratory fact sheets) throughout the duration of the study.

Seven cropping systems (three monoculture, two 2-yr rotations, and two 4-yr rotations) with three rates of $\mathrm{N}$ fertilizer were included in the study. Monocultures were continuous corn (Zea mays L.), continuous soybean [Glycine max (L.) Merr.], and continuous grain sorghum [Sorghum bicolor (L.) Moench]. Two-year rotations in the study were corn-soybean and grain sorghum-soybean, while 4-yr rotations were cornoat [Avena sativa (L.)] + clover $(80 \%$ yellow sweetclover [Melilotus officinalis Lam.] $+20 \%$ red clover [Trifolium pratense L.])-grain sorghum-soybean and corn-soybean-grain sorghum-oat + clover. A mixture of red clover and sweetclover was used to ensure a clover stand, as Melilotus spp. is 
subject to infestations of sweetclover weevil (Sitona cylidricollis). Each phase of every rotation occurred every year for a total of 15 rotation treatments. Treatments were assigned to experimental units ( 9 by $32 \mathrm{~m}$ ) in factorial combinations of rotation and crop within rotation in five randomized complete blocks in 1982. No fertilizer $\mathrm{N}$ was applied to any of the monoculture or rotation plots that cropping season.

Three subplots ( 9 by $10 \mathrm{~m}$ ) separated by $1-\mathrm{m}$ alleys were randomly assigned a 0 , low, or high $\mathrm{N}$ rate within each whole plot treatment starting with the 1983 cropping season. Nitrogen rates corresponded to 0,90 , or $180 \mathrm{~kg} \mathrm{~N}$ ha for corn and grain sorghum and 0,34 , or $68 \mathrm{~kg} \mathrm{~N} \mathrm{ha}^{-1}$ for soybean and oat + clover crops. Monoculture corn and grain sorghum plots assigned low and high fertilizer $\mathrm{N}$ rates received more and monoculture soybean plots less total $\mathrm{N}$ than plots in rotation. Each plot in rotation received the same amount of $\mathrm{N}$ when summed over a 4-yr period. Nitrogen was sidedressed as a liquid urea-ammonium nitrate solution $(28-0-0)$ in 1983 and 1984 and broadcast as granular ammonium nitrate (34-0-0) in subsequent years. Nitrogen applications were made in early May for oat + clover and in early to mid-June for corn, grain sorghum, and soybean.

Cultural practices were similar to those used by local producers. Previous crop residue on corn and grain sorghum plots was shredded in late November each year. All plots were tilled once or twice with a tandem disk just prior to planting each year for all crops. Crop varieties and hybrids were evaluated and changed if necessary every $4 \mathrm{yr}$ at completion of each full cycle of the longest rotations.

Oat was drilled as early as possible in the spring at $100 \mathrm{~kg}$ seed ha ${ }^{-1}$. Rhizobium-inoculated clover seed was seeded at $18 \mathrm{~kg} \mathrm{ha}^{-1}$ in the same operation. Planting dates were usually as early as soil conditions allowed, which ranged from midto late-March to mid-April for oat + clover.

Corn was seeded in $76-\mathrm{cm}$ rows at $47000 \mathrm{seed} \mathrm{ha}^{-1}$ in early May as soil conditions permitted. Weed control was accomplished using combinations of broad-spectrum herbicides in preemergence applications. Herbicides were selected for each rotation to obtain optimum weed control and to reduce carryover problems for successive crops in that rotation.

Soybean and grain sorghum were seeded in $76-\mathrm{cm}$ rows at rates of 370000 and 173000 seeds ha ${ }^{-1}$, respectively. Both crops were planted in mid- to late-May or early June as conditions permitted. Weed control and herbicide selection for each crop were accomplished using the same criteria mentioned above for corn.

Oat was harvested with a plot combine to determine grain yields in early July. Corn was harvested for grain in early October using a plot combine and soybean and grain sorghum were harvested with a plot combine for grain yield in midOctober each year.

Because of the diversity of crops, grain yields from 1983 through 1998 for each crop were normalized using the greatest individual plot yield by crop for that year as the maximum (greatest yield $=1$ ) and yield fractions were calculated. Once they had been normalized by crop, relative grain yields for all crops within a cropping system and $\mathrm{N}$ fertilizer treatment were combined, which resulted in relative yields for each cropping system and $\mathrm{N}$ fertilizer treatment in each year. Overall analyses of these $16 \mathrm{yr}$ of data were conducted to assess what effects cropping system and $\mathrm{N}$ fertilizer treatment have on the relative yields and their variability in those systems. This assessment provides an indication of the long-term effects of cropping systems and has implications regarding the potential for failure or success of management decisions in precision farming. All statistical analyses were performed using the
Table 1. Standard error of differences, significance, least significant differences (LSD) for rotation and $\mathbf{N}$ treatment main effects and interactions, and contrasts for normalized grain yields from 1983 through 1998 at Mead, NE.

\begin{tabular}{lccc}
\hline & \multicolumn{3}{c}{ Normalized yield } \\
\cline { 2 - 4 } Source & $\begin{array}{c}\text { Standard error } \\
\text { of difference }\end{array}$ & Significance & LSD (0.05) \\
\hline Rotation (R) & 0.015 & 0.001 & 0.03 \\
N treatment (N) & 0.007 & 0.001 & 0.01 \\
R $\times$ N & 0.021 & 0.001 & 0.04 \\
Contrasts & & & \\
\hline 2-yr vs. 4-yr & & NS & \\
Within 2-yr & & 0.005 & \\
Within 4-yr & & 0.043 & \\
\hline
\end{tabular}

PROC MIXED procedure in Statistical Analyses System (Littell et al., 1996).

\section{RESULTS AND DISCUSSION}

Cropping system and $\mathrm{N}$ treatment both significantly affected normalized yields at Mead, NE (Table 1). More importantly, the interaction between cropping system and $\mathrm{N}$ treatment was highly significant. As expected, those plots that received no $\mathrm{N}$ fertilizer, especially in monoculture corn and grain sorghum, had lower normalized yields throughout the $16 \mathrm{yr}$ of the study (Fig. 1 ). The effect of $\mathrm{N}$ treatment on normalized yields was fairly consistent in all the cropping systems compared except for continuous soybean, but it had a much greater affect in monoculture corn and grain sorghum systems.

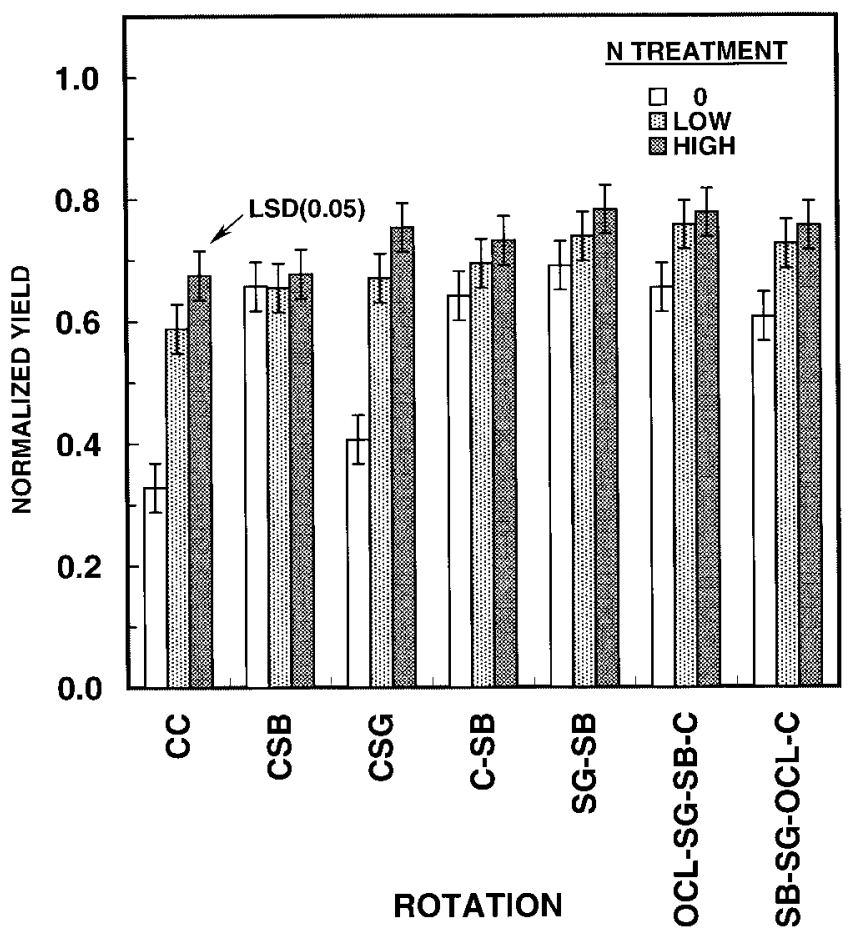

Fig. 1. Average normalized grain yields after $16 \mathrm{yr}$ as affected by rotation and $\mathrm{N}$ treatment in a long-term cropping system study at Mead, NE. Rotation abbreviations: $\mathbf{C C}=$ continuous corn, $\mathbf{C S B}=$ continuous soybean, $\mathbf{C S G}=$ continuous sorghum, $\mathbf{C}-\mathbf{S B}=$ cornsoybean, SG-SB = sorghum-soybean, OCL-SG-SB-C = oat + clover-sorghum-soybean-corn, SB-SG-OCL-C = soybean-sorghum-oat + clover-corn. 


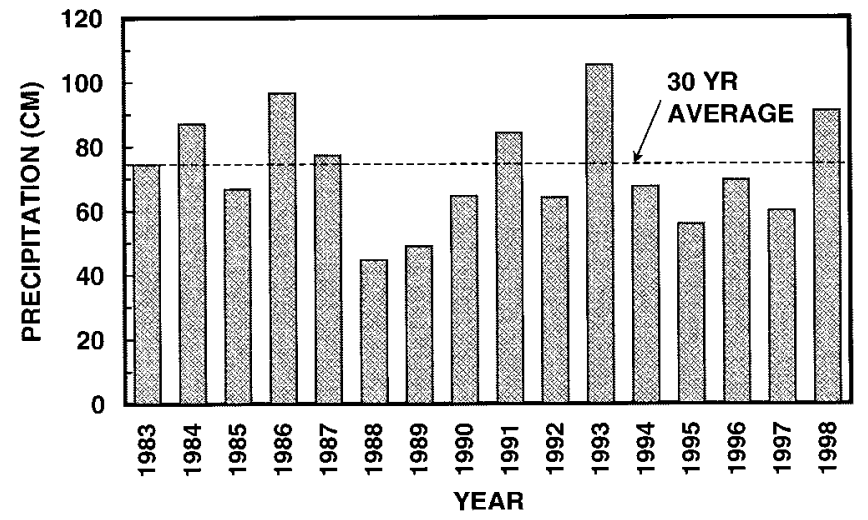

Fig. 2. Yearly precipitation at Mead, NE for 1983 through 1998.

Nitrogen fertilizer increased corn and grain sorghum yields significantly throughout the duration of the study (Peterson and Varvel, 1989 b,c) and that effect is apparent as one examines the normalized yields. Treatments in each of the cropping systems that received $\mathrm{N}$ fertilizer, except in continuous soybean, had significantly greater normalized yields.

Several things become apparent when normalized yields across and between cropping systems at the various $\mathrm{N}$ levels are examined. First, the importance of $\mathrm{N}$ fertilizer in monoculture corn and grain sorghum is strongly demonstrated. In monoculture corn, the high rate of $\mathrm{N}$ fertilizer is required to achieve normalized yield levels similar to normalized yields obtained in any of the 2- or 4-yr cropping systems without any $\mathrm{N}$ fertilizer or monoculture soybean at any $\mathrm{N}$ level. In monoculture sorghum, normalized yield at the high $\mathrm{N}$ fertilizer rate is significantly greater than normalized yield of monoculture corn at the same rate and similar to those of the 2- and 4-yr cropping systems with similar levels of $\mathrm{N}$ inputs. These results supported statements by Peterson and Varvel (1989b) about the general responsiveness to rotation of corn and grain sorghum. They ranked corn as the most responsive and grain sorghum as essentially nonresponsive to rotation as long as sufficient $\mathrm{N}$ fertilizer is applied. Normalized yields for the $16 \mathrm{yr}$ of the study provide strong evidence that this is indeed the case.

Nitrogen fertilizer did not affect normalized grain yields in continuous soybean, which is not unexpected since they are capable of fixing their own N. The lack of response to $\mathrm{N}$ fertilizer of normalized grain yields in continuous soybean over the $16 \mathrm{yr}$ are similar to those reported by Peterson and Varvel (1989a) with respect to soybean grain yield response to $\mathrm{N}$ fertilizer. Although normalized yields at the three $\mathrm{N}$ fertilizer levels for continuous soybean were very uniform for the duration of the study, they were less than those obtained in the 2and 4-yr cropping systems when $\mathrm{N}$ fertilizer was added, which would tend to support the benefits of crop rotation as compared with monocultures.

Comparisons of normalized yields between and among the 2- and 4-yr cropping systems were done even though the rotation by $\mathrm{N}$ treatment interaction was highly significant (Table 1). The change in normalized yields with the application of $\mathrm{N}$ fertilizer appeared to be similar within the 2- and 4-yr systems (Fig. 1), (i.e., no interaction). Using contrasts, the comparison between 2- and 4-yr cropping systems was not significant, but when these comparisons were made within 2- and 4-yr cropping systems, there were significant differences (Table 1). The comparison among 2-yr cropping systems indicated the average normalized yield of the grain sorghum-soybean rotation ( 0.74 ) was greater than the average normalized yield of the corn-soybean rotation (0.69). This difference was highly significant and may have been due to the same effect described above where grain sorghum normalized yields with $\mathrm{N}$ fertilizer in monoculture were much better than those of corn in monoculture with $\mathrm{N}$ fertilizer. The comparison among 4-yr cropping systems indicated a similar type of results with the average normalized yield of the oat + clovergrain sorghum-soybean-corn rotation (0.73) being significantly greater than the average normalized yield of the soybean-grain sorghum-oat + clover-corn rotation (0.70). The reason for this significant difference between the 4-yr cropping systems is not as apparent, but may be due to the greater levels of organic $\mathrm{C}$ in the surface $30 \mathrm{~cm}$ in 1992 for the oat + clover-grain sorghumsoybean-corn rotation $\left(14.8 \mathrm{~g} \mathrm{~kg}^{-1}\right)$ as compared with those in the soybean-grain sorghum-oat + clover-corn rotation (13.8 $\left.\mathrm{g} \mathrm{kg}^{-1}\right)$ reported by Varvel (1994). The greater level of organic $C$ (organic matter) may have resulted in more favorable water relations, which over the duration of the study may have resulted in the slightly greater normalized grain yields for that rotation.

These results demonstrate that greater normalized grain yields can be obtained in many cropping systems with proper management. Analyzed over long periods of time, which in this study encompasses large differences in yearly precipitation (Fig. 2), greater normalized grain yields are somewhat of an indication of reduced yield variability in those cropping systems because the normalized grain yields have been found to be significantly affected by rotation and $\mathrm{N}$ fertilizer treatments during this 16-yr period. If these normalized grain yields had not been found to be significantly affected by rotation and $\mathrm{N}$ fertilizer treatment, that would have been an indication that the year-to-year variation was too great and that none of the cropping systems were effective at reducing that variability, which was not the case.

Many times, as demonstrated in this study, reduced grain yield variability is obtained by varying some level of management or other input. As expected, $\mathrm{N}$ fertility, obtained from either fertilizer or legumes in the system, is probably one of the most, if not the most important component in reducing yield variability in grain production areas of the Great Plains and elsewhere.

This analysis provides evidence that many current management systems are prevalent because of their long-term effects on yield variability. Although previous comparisons such as this one have not been done, it appears that many producers and researchers have observed and therefore adopted these types of cropping systems. It becomes necessary for producers to decide 
how much risk they are willing to take and with information from a long-term study such as this recommendations can be formulated effectively.

\section{REFERENCES}

Eghball, B., and J.F. Power. 1995. Fractal description of temporal yield variability of ten crops in the United States. Agron. J. 87:152-156.

Eghball, B., and G.E. Varvel. 1997. Fractal analysis of temporal yield variability of crop sequences: Implications for site-specific management. Agron. J. 89:851-855.

Finlay, K.W., and G.N. Wilkinson. 1963. The analysis of adaptation in a plant breeding programme. Aust. J. Agric. Res. 14:742-754.

Littell, R.C., G.A. Milliken, W.W. Stroup, and R.D. Wolfinger. 1996. SAS system for mixed models. SAS Inst., Cary, NC.
Mead, R., J. Riley, K. Dear, and S.P. Singh. 1986. Stability comparison of intercropping and monocropping systems. Biometrics 42: 253-266.

Peterson, T.A., and G.E. Varvel. 1989a. Crop yield as affected by crop rotation and N rate. I. Soybean. Agron. J. 81:727-731.

Peterson, T.A., and G.E. Varvel. 1989b. Crop yield as affected by crop rotation and N rate. II. Sorghum. Agron. J. 81:731-734.

Peterson, T.A., and G.E. Varvel. 1989c. Crop yield as affected by crop rotation and N rate. III. Corn. Agron. J. 81:735-738.

Raun, W.R., H.J. Barreto, and R.L. Westerman. 1993. Use of stability analysis for long-term fertility experiments. Agron. J. 85:159-167.

Varvel, G.E. 1994. Rotation and nitrogen fertilization effects on changes in soil carbon and nitrogen. Soil Sci. Soc. Am. J. 86:319-325.

\title{
Residual Effects of Fall Deep Tillage on Soybean Yields and Net Returns on Tunica Clay Soil
}

\author{
Richard A. Wesley,* Lowrey A. Smith, and Stan R. Spurlock
}

\begin{abstract}
Seed yield of monocrop soybean [Glycine $\max ($ L.) Merr.] grown on nonirrigated clay soils in the Mississippi River alluvial flood plain has been consistently low and marginally profitable. Deep tillage (subsoiling) of certain clayey soils in the fall when the soil profile is dry significantly increases yields and net returns from this production system. Yields and net returns were evaluated for seven deep-till treatments and a conventional-till treatment that was disked annually (C). The deep-till treatments included subsoiling annually and once every second, third, fourth, and fifth year (DT1, DT2, DT3, DT4, and DT5, respectively), Paratill annually (PT1), and profile modification every fifth year (MP). Over the 5-yr study, DT1 produced the greatest yield $\left(3452 \mathrm{~kg} \mathrm{ha}^{-1}\right)$, which was $1016 \mathrm{~kg} \mathrm{ha}^{-1}(42 \%)$ above the average yield from C (2436 $\left.\mathrm{kg} \mathrm{ha}^{-1}\right)$. Yields from DT2, DT3, and PT1 were virtually identical and averaged only $198 \mathrm{~kg} \mathrm{ha}^{-1}(5-6 \%)$ less than the average yield from DT1, whereas yields from DT4 and DT5 averaged $291 \mathrm{~kg} \mathrm{ha}^{-1}(9 \%)$ and $613 \mathrm{~kg} \mathrm{ha}^{-1}(18 \%)$ less. Net returns from DT1 $\left(\$ 436 \mathrm{ha}^{-1}\right)$ averaged the highest, whereas returns from C $\left(\$ 220 \mathrm{ha}^{-1}\right)$ were the lowest. Net returns from DT2 and DT3 were within $5 \%$ of the net returns from DT1, whereas net returns from the DT4, DT5, PT1, and MP treatments respectively averaged 9, 26, 9 , and $31 \%$ less than returns from DT1. Thus, fall deep tillage should be performed at least once every $3 \mathrm{yr}$ to maximize and sustain higher yields and net returns from soybean grown on nonirrigated Tunica clay (clayey over loamy, smectitic, nonacid, thermic Vertic Haplaquept).
\end{abstract}

$\mathrm{C}$ LAYEY soils occupy approximately 3.7 million hectares or about $50 \%$ of the land area in the lower Mississippi River alluvial flood plain. These soils have been planted mainly to nonirrigated monocrop soybean. Seed yield of monocrop soybean grown in conventional (disked) production systems on these soils has been consistently low, ranging from 1300 to $1600 \mathrm{~kg} \mathrm{ha}^{-1}$ (Heatherly, 1983, 1988), and have been marginally prof-

Richard A. Wesley and Lowrey A. Smith, USDA-ARS, Application and Production Tech. Res. Unit, Stoneville, MS 38776; and Stan R. Spurlock, Economist, Dep. of Agric. Econ., Mississippi State, MS 39762. Received 27 Aug. 1999. *Corresponding author (rwesley@ars. usda.gov).

Published in Agron. J. 92:941-947 (2000). itable (Sanford, 1982; Wesley and Cooke, 1988; Wesley et al., 1994).

Montmorillonitic clays exhibit a high degree of swelling and shrinking as the moisture content in the soil profile cycles between wet and dry. As these soils approach maximum water-holding capacity, the clay fraction swells and severely restricts water movement into and through the soil profile. As water is removed from these soils, the clay fraction shrinks and vertical cracks often form within the profile. When this occurs during the summer growing season, roots of crops planted on these soils are damaged and often broken as the cracks widen over time.

The use of large equipment early in the season when the soil is wet may compact or reduce the productivity of the soil (Phillips and Kirkham, 1962; Gameda et al., 1987; Voorhees, 1985, 1987). When a soil is compacted, the soil particles are rearranged such that total pore space is decreased and bulk density is increased (Singer and Munns, 1987). In most cases, the large soil pores (macropores) are destroyed by the compactive force exerted on the soil. Compaction also increases soil strength, thereby increasing the resistance to root penetration. When plant roots cannot explore the entire soil structure, plant nutrients and water become positionally unavailable.

Compaction of soil, whether natural or artificial, alters the soil's condition and affects plant growth. Compaction adversely affects the content and movement of air, water, heat, and nutrients in the soil (Raney, 1971). Early research tended to suggest that an increase in the soil's bulk density would automatically reduce crop yield. Yield of potatoes (Solanum tuberosum L.) was reduced 22\% (Saini and Lantagne, 1974), whereas Phillips and Kirkham (1962) and Morris (1975) reported

Abbreviations: C, conventional disk annually; DT1, deep-till annually DT2, deep-till once every 2 yr; DT3, deep-till once every 3 yr; DT4, deep-till once every 4 yr; DT5, deep-till once every 5 yr; MP, modified profile once every $5 \mathrm{yr}$; PT1, Paratill annually; POST, postemergence. 